\title{
Probabilistic Assessment of Bored Pile Wall: A Slope Stabilisation Technique
}

\author{
Sadaf Qasim ${ }^{1}{ }^{*}$, Danish Kazmi ${ }^{1}$, Indra S.H. Harahap ${ }^{2}$, Muhammad Imran², and \\ Abdul Razzaque Sandhu ${ }^{3}$ \\ ${ }^{1}$ Department of Civil Engineering, NED University of Engineering \& Technology, Karachi, Pakistan \\ ${ }^{2}$ Department of Civil and Environmental Engineering, Universiti Teknologi Petronas, Perak, Malaysia \\ ${ }^{3}$ Department of Civil Engineering, Mehran University of Engineering \& Technology, SZAB Campus, \\ Khairpur, Pakistan
}

\begin{abstract}
One of the potential applications of bored piles is the construction of a retaining wall where the piles are closely installed and the spacing between them is often grouted to build a waterproof retaining wall. Based on previous experience, it is observed that the selection of an appropriate retaining structure is crucial to the strength and stability of a structure, provided that the design of retaining structure is adequate and it satisfies the structural requirements. This study considers a Malaysian slope, Bukit Antarabangsa, to perform the probabilistic stability analysis of bored piles. Statistical tools of FORM and Monte Carlo are used to demonstrate the influence of soil parameters on the reliability levels of structure. This paper also presents the load and resistance factors which are developed to counter the rotational and flexural failure modes of a bored pile wall. It is expected that this study will provide a support to the Malaysian geotechnical industry to integrate a reliability-based design for slope construction.
\end{abstract}

\section{Introduction}

Slopes, in soils and rocks, originates through natural or in-made processes. Highways, dams, levees, canals and stockpiles are erected, by shaping the sideways of the soil because slopes are commonly less pricey than constructing the wall. Natural forces such as wind and water change the topography of earth, often fashioning unstable slopes. Most of the landslide occurs on the cut slopes or embankment along roads, highway and sometimes within the vicinity of thickly populated localities, particularly in the high terrain. Thus, a proper understanding, monitoring and management of slope is necessary to ensure its stability and minimize the extent of any damage.

In Malaysia, the slope failures, includes existing slopes and newly completed slopes, have caused a considerable compensatory or non-compensatory losses. The previous landslide of Hulu Langat (2011) and Bukit Antarabangsa (2008) once again cautioned the Malaysian geotechnical industry to reassess their construction modalities and design methods. MohdNoor et.al [1] also reported these landslides and discussed some slope stabilisation methods

${ }^{*}$ Corresponding author: nuzhaterum@gmail.com 
for residential areas based on the observations taken from the few districts of Perak. Though, for slope stabilisation, the construction of a retaining structure is relatively an expensive method however it is often preferred due to its adaptability in a dense area. It typically works by countering the downward forces of the soil mass and include gravity types of retaining wall, cantilever wall, contiguous bored piles, cassion, and steel sheet pile. Closely spaced bored piles can be used to build a retaining wall, possibly for the construction of deep basement plus cut and cover tunnel. The piles may be installed such that they are nearly in contact with each other. The spaces between the piles are grouted usually to shape up a waterproof retaining wall.

Among other retaining structures, the structure of piles is commonly used where space is restricted or excavation is incongruous. In slope stabilisation, contiguous bored piles appear to be a realistic choice compared to other retaining structures. In fact, the grouping of the practicable remedial works must be handled according to the site conditions [2].

Mariappan [3] also discussed some remediation methods for the Bukit Antarabangsa slope. The proposed methods include the use of caissons and soil nailed walls for the rehabilitation of slope. Essentially, caissons are one of the types of bored pile walls which are continuous concrete walls constructed of interlocking vertical concrete piles. They are somewhat impermeable and restricts the flow of groundwater into a construction site.

The selection of an appropriate retaining structure contributes to the strengthening and stabilisation of slope, however, the methods used in designing are often incomprehensive. For example, the approach of deterministic analysis does not consider the variability in input parameters which can be quantified using reliability/probabilistic analysis. Probabilistic techniques allow an engineer to understand the major sources of risk and facilitate in making right engineering judgement by showing the reliability of alternatives. In fact, the utility and role of reliability in geotechnical engineering cannot be practiced without having a clear perspective of the probability and risk assessment principles alongside their methods [4], [5].

This study considers the remedial works performed on a Malaysian slope, Bukit Antarabangsa, which was failed in 2008, to investigate its safety level by applying reliability theory. Based on the geological atlas of Malaysia and site studies, the failure area consists of granitic bedrock formation. The remedial works were planned by constructing a suitable well-compacted earth fill and caissons to increase the overall stability and to avoid toe basal failure. The un-failed section of slope was also aimed to be reinforced using soil nails and pressure grouting for increasing the overall factor of safety (Fig.1.)

Statistical tools, such as first-order reliability method (FORM) and Monte Carlo (MC) simulation, are utilized in this study to work out the reliability index of two dominant failure modes: rotation about the base and flexure failure. The influence on reliability indices is observed by fluctuating the unit weight and friction of soil using the coefficient of variation (COV). Further, the resistance factors are also developed to counter the above failure modes. In pile wall, the governing failure modes are slightly different compared to other gravity and cantilever retaining walls.

\section{Stability criteria for piled wall}

Under static conditions, retaining structures are acted upon by body forces linked to the mass of the wall, by soil pressure and by external forces. A well designed retaining structure must have the capacity to maintain the equilibrium of these forces, without disturbing the shear strength of the soil. Due to some external impacts/ forces, changes can occur in the equilibrium of soil mass and the internal forces. This distressed equilibrium may lead to permanent deformation in the retaining structure so; the retaining structure's design must have the balance against different types of instabilities like sliding, overturning etc. 


$$
g=M_{R}-M_{O}
$$

Where $M_{R}$ the resisting moment is basically created through self-weight of the wall and $M_{O}$ is the overturning moment produced by rotation about the toe.

In sliding failure mode driving force causes retaining wall to slide is the lateral earth pressure from soil and surcharge. The forces that resist sliding are passive pressure at toe, the friction at the base and the passive pressure against the key is used. The limit state function of sliding failure mode is:

$$
g=\left(F_{R}+P_{p}\right)-P_{h}
$$

\section{Limit state function}

The rotational stability of any piled wall that holds on to soil, to height $H$ and embedded to a depth $D$ below the dredge line, can be estimated as the share of the moments that resists the rotation $(M r)$ and moments causing the rotation $\left(M_{d}\right)$. This share of $\left(M_{r} / M_{d}\right)$ is termed as moment ratio. In a broader sense, the resisting moment is the outcome of the passive pressure and disturbing moment is the result of the active pressures.

When the stability adjacent to rotational failure about the base point is allotted as the limit state function of a sheet pile wall, reliability for the wall can be expressed as the probability that the resisting moment about the base point of sheet pile wall is greater than the disturbing moment around the base point. This definition can be articulated with the safety margin in opposition to rotational failure as follows:

$$
g=\frac{M_{r}}{M_{d}}-1
$$

The same is when the stability against the flexural failure of pile wall is allotted as the limit state function; reliability for the wall may be explained in terms of probability. It shows that the section modulus of the pile wall must be the minimum section modulus required to keep the structure stable. The minimum section of the pile wall has to be chosen on the basis of the maximum bending moment and the allowable bending stress of the material. This definition can be presented with the safety margin aligned with flexural failure as follows:

$$
g=\frac{s}{s_{\min }}-1
$$

Where

$\mathrm{s}=$ section modulus of the pile wall and

$\mathrm{S}_{\min }=$ the minimum section modulus required to maintain wall stability

In case of contiguous bored pile walls, the diameter has to be considered if referring to section modulus of a circular section, normally defined as: $\left(d^{3} \frac{\pi}{36}\right)$

Bukit Antarabangsa is a hillside township situated in Ulu Klang, Selangor. It is geographically located at $3^{\circ} 12^{\prime} 00^{\prime \prime}$ north latitude and $101^{\circ} 46^{\prime} 01^{\prime \prime}$ east. Due to its close proximity to Kuala Lumpur, there has been a rapid increase in infrastructure development and construction projects in this area. Land types vary from the fat terrain of peat swamp forests, grassland, ex-mine sites and scrub areas to a very hilly area of natural forest $420 \mathrm{~m}$ above sea level The soil consists of $45 \%$ sand, $37.5 \%$ clay and $17.5 \%$ silt . Based on the given texture, the soil type is clay loam. The considered soil profile, geometrical configurations such as the pile diameter, pile spacing, pile length and geology have been confirmed through the work of previous literature [3], [6], [7] and [8]. 


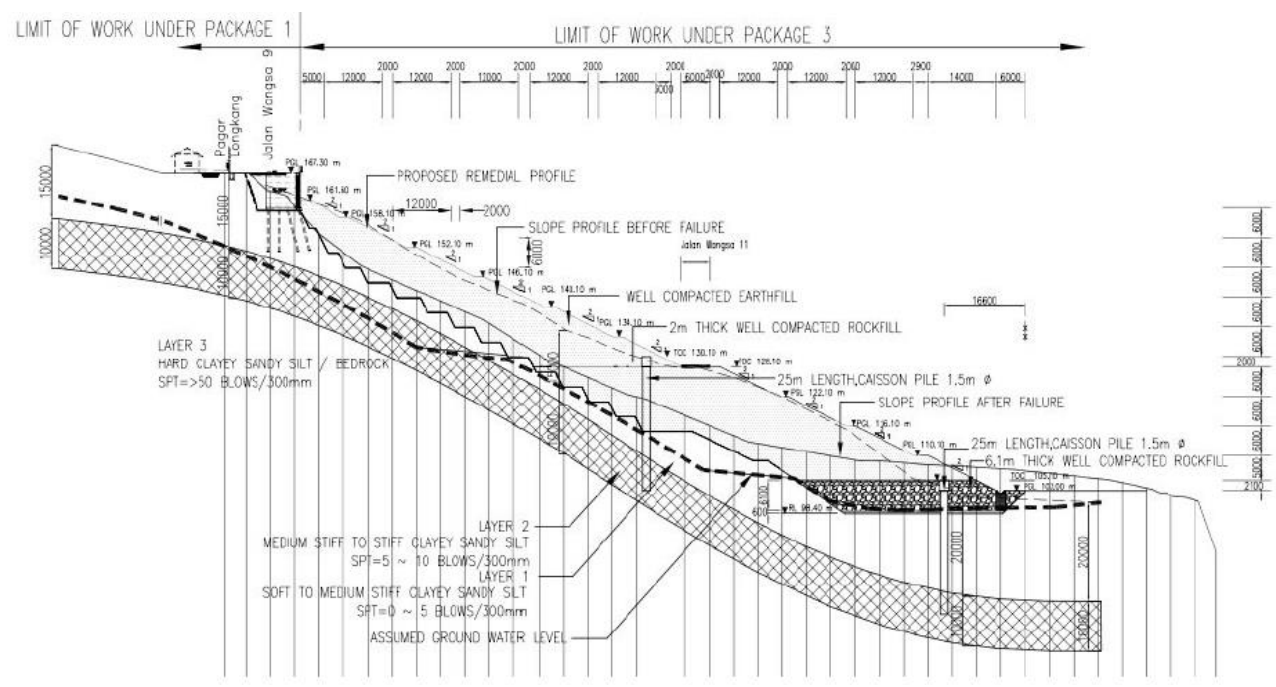

Fig. 1. Bukit Antarabangsa Failed Slope Remedial Works [3]

\section{Results and discussion}

The typical approach used in the designing of engineering structures is to consider the relationship between capability $C$ (strength or resisting force) of the element and the requirement $\mathrm{D}$ (stress or disturbing force). The safety factor of the structure is defined as $F=C / D$ and failure is expected to occur when $F$ is less than 1 .

Generally, a geotechnical engineer often relies on the safety factor approach to cover any risk related to the retaining structure. However, the factor of safety approach does not have the capacity to quantify the probability of failure, or level of risk [9], [10], [11].

probabilistic approach to evaluate the geotechnical stability of a structure provides a systematic way of dealing with the uncertainties. In probabilistic terms, the uncertainties can be quantitatively linked to the reliability in the design of a slope. The application of a riskbased design, which engineers can use on the basis of practical experience, judgement, and statistical information, is advantageous for analysing the stability of a slope for an allowable risk criterion [6]. A reliability analysis entails calculations of failure probabilities denoted by the probability of failure $\left(\mathrm{P}_{\mathrm{f}}\right)$.

This study has considered two statistical tools, FORM and Monte Carlo simulation, for the probabilistic assessment of the selected structure of piled wall [2]. The FORM is used to work out the reliability index (Refer Table 1 to Table 4) and to assess the chances of failure (in linking with uncertain parameters like angle of friction and soil unit weight ) Monte Carlo simulation has been taken into account (Refer Table 2) [12]. In actual, FORM is composed of the following steps:

- $\quad$ Limit state is $\mathrm{g}(\mathrm{x})$. Failure when $\mathrm{g}<0$

- Linear approximation of limit state along with the postulation that random variables are normal

- The limit state is also normal variable

- Reliability index is the distance of the mean of $g$ from zero considered in standard deviations.

Referring to Monte Carlo Methods [13], it is originally a class of computational algorithms that trust on repeated random sampling to evaluate their results. Monte Carlo 
simulation is a method of reliability analysis that should be used only when the system to be analysed becomes too intricate for use of simpler methods of reliability analysis, such as, the reliability index method. In Monte Carlo simulations, each random variable is showing by a probability density function and repeated conservative analyses are made (iterations) by replacing the values of the random variables using a random number generator. To obtain an accurate solution for Monte Carlo simulation, thousands of these conventional analyses must be carried out. The simpler methods of reliability analysis can be preferred in the cases where they are applicable since the Monte Carlo simulation is costly in terms of time despite being authentic and efficient. The probability of failure through Monte Carlo technique can be expressed as:

$$
P_{f}=\frac{\text { No of failures }}{\text { Total number of trials }}
$$

Table 1. Probabilistic Assessment of Bored Pile Wall in Rotational Failure with Different COVs of Unit weight of Soil $(\mathrm{H}=8.8 \mathrm{~m} \mathrm{D}=14 \mathrm{~m})$.

\begin{tabular}{|c|c|c|c|}
\hline $\begin{array}{c}\text { COVs } \\
\text { Unit weight }\end{array}$ & $\begin{array}{c}\text { COVs } \\
\text { Angle of Friction }\end{array}$ & $\begin{array}{c}\text { Probability of } \\
\text { failure } \\
(\mathrm{Pf}) \\
(\mathrm{MC})\end{array}$ & $\begin{array}{c}\text { Reliability Index } \\
(\beta) \\
(\mathrm{FORM})\end{array}$ \\
\hline 0.57 & 0.031 & 0.00067 & 3.9 \\
\hline 0.76 & 0.031 & 0.00086 & 3.5 \\
\hline 0.95 & 0.031 & 0.00095 & 3.16 \\
\hline 1.14 & 0.031 & 0.00078 & 2.98 \\
\hline 1.33 & 0.031 & 0.00106 & 2.45 \\
\hline
\end{tabular}

Table 2. Probabilistic Assessment of Bored Pile Wall in Rotational Failure with Different COVs of Angle of Friction of soil $(\mathrm{H}=8.8 \mathrm{~m} \mathrm{D}=14 \mathrm{~m})$.

\begin{tabular}{|c|c|c|c|}
\hline $\begin{array}{c}\text { COVs } \\
\text { Unit weight }\end{array}$ & $\begin{array}{c}\text { COVs } \\
\text { Angle of Friction }\end{array}$ & $\begin{array}{c}\text { Probability of failure } \\
(\mathrm{Pf}) \\
(\mathrm{MC})\end{array}$ & $\begin{array}{c}\text { Reliability Index } \\
(\beta) \\
(\mathrm{FORM})\end{array}$ \\
\hline 0.95 & 0.01 & - & - \\
\hline 0.95 & 0.021 & - & - \\
\hline 0.95 & 0.031 & 0.00095 & 2.16 \\
\hline 0.95 & 0.041 & 0.00953 & 1.97 \\
\hline 0.95 & 0.051 & 0.02997 & \\
\hline
\end{tabular}

Table 3. Probabilistic Assessment of Bored Pile Wall in Flexure Failure with Different COVs of Unit weight of Soil $(\mathrm{H}=8.8 \mathrm{~m} \mathrm{D}=14 \mathrm{~m})$

\begin{tabular}{|l|l|l|l|}
\hline $\begin{array}{c}\text { COVs } \\
\text { Unit weight }\end{array}$ & $\begin{array}{c}\text { COVs } \\
\text { Angle of Friction }\end{array}$ & $\begin{array}{c}\text { Probability of failure } \\
(\mathrm{Pf}) \\
(\mathrm{MC})\end{array}$ & $\begin{array}{c}\text { Reliability Index } \\
(\beta) \\
(\mathrm{FORM})\end{array}$ \\
\hline 0.57 & 0.031 & 0.02 & 2.34 \\
\hline 0.76 & 0.031 & 0.06 & 1.68 \\
\hline 0.95 & 0.031 & 0.11 & 1.29 \\
\hline 1.14 & 0.031 & 0.15 & 1.02 \\
\hline 1.33 & 0.031 & 0.18 & 0.89 \\
\hline
\end{tabular}


Table 4. Probabilistic Assessment of Bored Pile Wall in Flexure Failure with Different COVs of Angle of Friction of Soil $(\mathrm{H}=8.8 \mathrm{~m} \mathrm{D}=14 \mathrm{~m})$

\begin{tabular}{|l|l|l|l|}
\hline $\begin{array}{c}\text { COVs } \\
\text { Unit weight }\end{array}$ & $\begin{array}{c}\text { COVs } \\
\text { Angle of Friction }\end{array}$ & $\begin{array}{c}\text { Probability of failure } \\
(\mathrm{Pf}) \\
(\mathrm{MC})\end{array}$ & $\begin{array}{c}\text { Reliability Index } \\
(\beta) \\
(\mathrm{FORM})\end{array}$ \\
\hline 0.95 & 0.01 & 0.028 & 2.23 \\
\hline 0.95 & 0.021 & 0.161 & 1.43 \\
\hline 0.95 & 0.031 & 0.11 & 1.29 \\
\hline 0.95 & 0.041 & 0.31 & 1.01 \\
\hline 0.95 & 0.051 & 0.35 & 0.86 \\
\hline
\end{tabular}

Table 5.Probabilistic Assessment of Bored Pile Wall in Flexure Failure with Different COVs of Material Strength (Concrete)

\begin{tabular}{|c|c|c|c|c|}
\hline $\begin{array}{c}\text { COVs } \\
\text { Unit } \\
\text { weight }\end{array}$ & $\begin{array}{c}\text { COVs } \\
\text { Angle of } \\
\text { Friction }\end{array}$ & $\begin{array}{c}\text { COVs } \\
\text { Material } \\
\text { strength }\end{array}$ & $\begin{array}{c}\text { Probability of failure } \\
(\mathrm{Pf}) \\
(\mathrm{MC})\end{array}$ & $\begin{array}{c}\text { Reliability Index } \\
(\beta) \\
(\text { FORM) }\end{array}$ \\
\hline 5 & 6 & 2 & 0.026 & 2.97 \\
\hline 5 & 6 & 3 & 0.034 & 2.26 \\
\hline 5 & 6 & 4 & 0.090 & 1.86 \\
\hline 5 & 6 & 5 & 0.13 & 1.22 \\
\hline 5 & 6 & 6 & 0.11 & 0.98 \\
\hline
\end{tabular}

Table 6 Resistance/Load Factors of Bored Pile Wall in Rotational Failure with Different COVs of Unit weight of Soil

\begin{tabular}{|c|c|c|c|c|c|c|}
\hline \multirow{2}{*}{$\begin{array}{l}\text { COVs } \\
\text { Unit } \\
\text { weight }\end{array}$} & \multirow{2}{*}{$\begin{array}{l}\text { COVs } \\
\text { Angle of } \\
\text { Friction }\end{array}$} & \multirow{2}{*}{$\begin{array}{l}\text { Reliability } \\
\text { Index }(\beta) \\
(\text { FORM })\end{array}$} & \multicolumn{2}{|c|}{ Resistance Factors } & \multicolumn{2}{|c|}{ Load Factors } \\
\hline & & & $\begin{array}{l}\text { Unit } \\
\text { weight }\end{array}$ & $\begin{array}{l}\text { Angle of } \\
\text { Friction }\end{array}$ & $\begin{array}{l}\text { Unit } \\
\text { weight }\end{array}$ & $\begin{array}{l}\text { Angle of } \\
\text { Friction }\end{array}$ \\
\hline 3 & 6 & 3.9 & 0.88 & 0.99 & 1.11 & 1.01 \\
\hline 4 & 6 & 3.5 & 0.86 & 0.97 & 1.02 & 1.17 \\
\hline 5 & 6 & 3.16 & 0.84 & 0.98 & 1.01 & 1.13 \\
\hline 6 & 6 & 2.98 & 0.82 & 0.99 & 1.005 & 1.12 \\
\hline 7 & 6 & 2.45 & 0.82 & 0.97 & 1.001 & 1.09 \\
\hline
\end{tabular}

Table 7. Resistance/Load Factors of Bored Pile Wall in Rotational Failure with Different COVs of Unit weight of Soil

\begin{tabular}{|c|c|c|c|c|c|c|}
\hline \multirow{2}{*}{$\begin{array}{c}\text { COVs } \\
\text { Unit } \\
\text { weight }\end{array}$} & \multirow{2}{*}{$\begin{array}{l}\text { COVs } \\
\text { Angle of } \\
\text { Friction }\end{array}$} & \multirow{2}{*}{$\begin{array}{l}\text { Reliability } \\
\text { Index }(\beta) \\
(\text { FORM) }\end{array}$} & \multicolumn{2}{|c|}{ Resistance Factors } & \multicolumn{2}{|c|}{ Load Factors } \\
\hline & & & $\begin{array}{c}\text { Unit } \\
\text { weight }\end{array}$ & $\begin{array}{c}\text { Angle } \\
\text { of } \\
\text { Friction }\end{array}$ & $\begin{array}{c}\text { Unit } \\
\text { weight }\end{array}$ & $\begin{array}{l}\text { Angle of } \\
\text { Friction }\end{array}$ \\
\hline 5 & 2 & - & - & - & - & - \\
\hline 5 & 4 & - & - & - & - & - \\
\hline 5 & 6 & 3.16 & 0.90 & 0.99 & 1.00 & 1.15 \\
\hline 5 & 8 & 2.67 & 0.93 & 0.99 & 1.00 & 1.18 \\
\hline 5 & 10 & 1.97 & 0.96 & 0.99 & 1.02 & 1.17 \\
\hline
\end{tabular}


Table 오류! 지정한 스타일은 사용되지 않습니다.. Probabilistic Assessment of Bored Pile Wall in Flexure Failure with Different COVs of Unit weight of Soil

\begin{tabular}{|l|l|l|c|c|c|c|}
\hline COVs & COVs & Reliability & \multicolumn{2}{|c|}{ Resistance Factors } & \multicolumn{2}{|c|}{ Load Factors } \\
\cline { 4 - 7 } $\begin{array}{l}\text { Unit } \\
\text { weight }\end{array}$ & $\begin{array}{l}\text { Angle of } \\
\text { Friction }\end{array}$ & $\begin{array}{c}\text { Index }(\beta) \\
(\text { FORM })\end{array}$ & $\begin{array}{c}\text { Unit } \\
\text { weight }\end{array}$ & $\begin{array}{c}\text { Angle of } \\
\text { Friction }\end{array}$ & $\begin{array}{c}\text { Unit } \\
\text { weight }\end{array}$ & $\begin{array}{c}\text { Angle of } \\
\text { Friction }\end{array}$ \\
\hline 3 & 6 & 2.34 & NA & NA & 1.05 & 1.12 \\
\hline 4 & 6 & 1.68 & NA & NA & 1.00 & 1.08 \\
\hline 5 & 6 & 1.29 & NA & NA & 1.02 & 1.05 \\
\hline 6 & 6 & 1.02 & NA & NA & 1.01 & 1.07 \\
\hline 7 & 6 & 0.89 & NA & NA & 1.01 & 1.03 \\
\hline
\end{tabular}

Table 9. Probabilistic Assessment of Bored Pile Wall in Flexure Failure with Different COVs of Angle of Friction of Soil

\begin{tabular}{|l|l|l|c|c|c|c|}
\hline COVs & COVs & Reliability & \multicolumn{2}{|c|}{ Resistance Factors } & \multicolumn{2}{|c|}{ Load Factors } \\
\cline { 4 - 7 } $\begin{array}{l}\text { Unit } \\
\text { weight }\end{array}$ & Angle of & Index $(\beta)$ & Unit & Angle of & Unit & Angle of \\
Feight & Friction \\
\hline 5 & 2 & 2.23 & NA & NA & 1.0 & 1.02 \\
\hline 5 & 4 & 1.43 & NA & NA & 1.02 & 1.03 \\
\hline 5 & 6 & 1.29 & NA & NA & 1.02 & 1.05 \\
\hline 5 & 8 & 1.01 & NA & NA & 1.0 & 1.07 \\
\hline 5 & 10 & 0.86 & NA & NA & 1.01 & 1.09 \\
\hline
\end{tabular}

Table 10. Probabilistic Assessment of Bored Pile Wall in Flexure Failure with Different COVs of Material Strength of Concrete

\begin{tabular}{|c|c|c|c|c|c|c|}
\hline \multirow{2}{*}{$\begin{array}{c}\text { COVs } \\
\text { Unit } \\
\text { weight }\end{array}$} & $\begin{array}{c}\text { COVs } \\
\text { Angle of } \\
\text { Friction }\end{array}$ & $\begin{array}{c}\text { COVs } \\
\text { Material } \\
\text { strength }\end{array}$ & $\begin{array}{c}\text { Reliability } \\
\text { Index }(\beta) \\
(\text { FORM })\end{array}$ & $\begin{array}{c}\text { Resistance } \\
\text { Factors }\end{array}$ & \multicolumn{2}{|c|}{$\begin{array}{c}\text { Load } \\
\text { Factors }\end{array}$} \\
\hline 5 & 6 & 2 & 2.97 & $\begin{array}{c}\text { Material } \\
\text { strength }\end{array}$ & $\begin{array}{c}\text { Unit } \\
\text { weight }\end{array}$ & $\begin{array}{c}\text { Angle of } \\
\text { Friction }\end{array}$ \\
\hline 5 & 6 & 3 & 2.26 & 0.89 & 1.0 & 1.12 \\
\hline 5 & 6 & 4 & 1.86 & 0.93 & 1.03 & 1.09 \\
\hline 5 & 6 & 5 & 1.22 & 0.96 & 1.04 & 1.08 \\
\hline 5 & 6 & 6 & 0.98 & 0.96 & 1.07 & 1.05 \\
\hline
\end{tabular}

For the retaining structure of caisson or pile wall, the governing failure modes are rotational and flexural failure mode. In the rotational mode, soil unit weight and friction are considered as random variables to observe its impact on reliability index and the probability of failure through Monte Carlo simulation and first order reliability method (Table 1 to Table 5). In case of rotational failure, the COVs of the angle of friction lays great effect on reliability index and the probability of failure. For example, the probability of failure and reliability index at $6 \% \mathrm{COV}$ of unit weight are 0.00095 and 3.16 respectively. But if the COV increases from $6 \%$ to $8 \%$, the reliability index and probability of failure become 2.67 and 0.00953 . In the case of flexural failure, all three random variables are dominating side by side while the unit weight of soil and angle of friction both imposes an equal level of influence on reliability levels (Refer Table 3 and 4). Using the same methodology as Qasim, Harahap et al. [14], the load and resistance factors for contiguous bored piles are determined. In case of rotational failure, and at different COVs of unit weight and angle of friction, the load and resistance factors of both variables are determined (Refer Table 5, 6 and 7). In rotational failure, both variables (angle of friction and unit weight) acts simultaneously as driving and resisting 
forces. This, in principle, supports the theory that, in slope stability applications and earth retaining structures, a soil parameter may act as a resisting component or as a driving component or may contribute to both resisting and driving components. Thus, in this condition, the demand of separate factors for various design variables, contributing to the overall resistance and load effects for the limit state, arises [11], [15]. In flexural failure mode, along with angle of friction and unit weight of the soil, the compressive strength of concrete is also considered to observe changes in load/resistance factors due to variation in the unit weight and angle of internal friction of soil. (Refer Table 8, 9, and 10)

\section{CONCLUSION}

This study shows the effect of different variables on the failure modes of a bored pile and the outcomes of this study can potentially facilitate in building a systematic framework for the assessment of pile walls by reliability-based load resistance factor design (LRFD). The steps that may cover in such framework are: a) the design equations are recognized; b) all variables shown in the design equation are considered to identify all component quantities; probabilistic models for the uncertain quantities are developed using all available data; d) reliability analysis is used to determine the limit state values corresponding to a set of nominal design values at a specified reliability index; e) resistance factors are determined algebraically from the consequent nominal and limit state values. Additionally, all the resistance factor results from this study can potentially assist in developing future LRFD codes for the design of bored piles.

\section{References}

1. Mizal-Azzmi, N., N. Mohd-Noor, and N. Jamaludin, Geotechnical Approaches for Slope Stabilization in Residential Area. Procedia Engineering, 2011. 20(0): p. 474-482.

2. Chen, C.S. and C.S. Lim, Some Case Histories of Slope Remedial Works, in Geotechnical Engineering for Disaster Prevention and Rehabilitation2005, 3rd International Conference on Geotechnical Engineering combined with 9th Yearly Meeting of the Indonesian Society for Geotechnical Engineering:: Java, Indonesia.

3. Mariappan, S., et al., Remedial Measures Adopted for Slope Failure at Bukit Antarabangsa, Malaysia. Enecal Consultants Sdn Bhd, Jabatan Kerja Raya, Mohd Asbi \& Associates, Kuala Lumpur, Malaysia, 2011.

4. Low, B.K., Reliability based Design Applied to Retaining Walls. Geotechnique 2005 55(1): p. 63-75.

5. Whitman, R., Evaluating Calculated Risk in Geotechnical Engineering. Journal of Geotechnical 1 Engineering Divison ASCE, 1984. 110(2): p. 145-188.

6. Hassaballa AA, A.O., Pradhan B, Extraction of soil moisture from RADARSAT-1 and its role in the formation of the 6 Dec 2008 landslide at Bukit Antarabangsa, Kuala Lumpur. . Arab J Geosci, 2014. 7(7): p. 2831-2840

7. Mukhlisin M, I.I., Yaacob WZW, ElShafe A, Taha MR, Soil slope deformation behavior in relation to soil water interaction based on centrifuge physical modeling. nt J Phys Sci 2011. 6(13): p.:3126-3133

8. Jebar MN, P.B., Tehrany MS, Optimization of landslide conditioning factors using very high-resolution airborne laser scanning (LiDAR) data at catchment scale. Remote Sens Environ, 2014. 152: p. 150-165. 
9. Whitman, R., Organizing and Evaluating Uncertainty in Geotechnical Engineering. Journal of Geotechnical and Geoenvironmental Engineering, 2000(july).

10. Duncan, J.M., Factors of Safety and Reliability in Geotechnical Engineering. Journal of Geotechnical and Geoenvironmental Engineering, 2000. 126(4): p. 307-316.

11. Baecher, G.B. and J.T. Christian, Reliability and Statistics in Geotechnical Engineering2003: John Wiley \& Sons Inc.

12. Structural Reliability Analysis of Marine Structures. Det Norske Veritas, 1992. Classification Notes.

13. Siddall, J.N., Probabilistic Engineering Planning and Design Principles and Applications 1983, M. Dekker New York

14. Sadaf Qasim, et al., Investigating the potential of soil-nail retaining structures as a slope strengthening remedy by capitalizing on reliability analysis technique,, in Engineering Challenges for Sustainable Future. Taylor \& Francis Group, 2016. p. 27-31.

15. Lazarte, C. and G.B. Baecher. LRFD for Soil Nailing Design and Specifications. in LSD2003: International Workshop on Limit State design in Geotechnical Engineering Practice. 2003. Cambridge, Massachusetts. 